\title{
Фехтування на Іграх XXXII Олімпіади в Токіо: підсумки і напрями вдосконалення олімпійської підготовки
}

\author{
Олександр Дрюков ${ }^{1}$ Володимир Дрюков²
}

${ }^{1}$ Хмельницький інститут соціальних технологій, м. Хмельницький, Україна

${ }^{2}$ Національний університет кораблебудування ім. адмірала Макарова,

м. Миколаїв, Україна

Анотація. Розглянуто і проаналізовано виступи українських спортсменів на Іграх XXXII Олімпіади, а також здійснено аналіз досліджень проблеми удосконалення їх підготовки. Мета. Проаналізувати спортивні досягнення українських фехтувальників на Іграх Олімпіади в Токіо. Методи. Аналіз літературних джерел, даних мережі Інтернет, технічних протоколів. Результати. У ході дослідження виявлено, що результати виступів збірної команди України на Іграх XXXII Олімпіади можна вважати задовільним. Відмічається, що сьогодні система розвитку фехтування в Україні не є оптимальною. Спостерігається явний десріцит сучасних центрів підготовки спортсменів, неефективне бюджетне і позабюджетне фінансування, недосконалість нормативноправового, організаційно-управлінського, науково-методичного, медичного, інформаційного та кадрового забезпечення. Таким чином, стратегія розвитку фехтування у сучасних умовах розвитку України вимагає формування та наукового обґрунтування концептуальних основ для успішного та динамічного розвитку цього виду спорту. Для оцінювання сучасного стану функціонування і розвитку фехтування було проведено PEST-аналіз. Встановлено, що в групі політико-правових факторів найбільш значущими є: законодавча підтримка розвитку видів спорту; у групі економічних - фінансування і матеріально-технічне забезпечення спортивних шкіл; у групі соціальних - рівень тренерсько-викладацьких кадрів та умов праці у спортивних школах; в групі технологічних - інноваційні технології та їх вплив на розвиток фехтування. Результати проведеного дослідження свідчать, що розвиток фехтування гальмує ряд факторів макросередовища і умов, які потребують проведення певних реформ. Як показує дослідження, процес функціонування і розвитку фехтування в сучасних умовах потребує формування принципово нових економічних основ і пошуку організаційно-правових форм їх функціонування. На нашу думку, це перехід від екстенсивної моделі розвитку видів спорту, яка сьогодні використовується в Україні, до інноваційної. Таким чином, для забезпечення у подальшому завоювання призових місць на Олімпійських іграх необхідна розробка моделі інноваційного розвитку фехтування на основі стратегічного партнерства між державою, громадськими спортивними організаціями, наукою, сферою освіти і бізнесу.

Ключові слова: Ігри Олімпіад, підсумки, PEST-аналіз, фехтування.

\section{Oleksandr Driukov, Volodymyr Driukov}

\section{FENCING AT THE XXXII OLYMPIC GAMES IN TOKYO: RESULTS AND DIRECTIONS OF IMPROVING OLYMPIC TRAINING}

Abstract. The performances of Ukrainian athletes at the Games of XXXII Olympiad were examined and analyzed, as well as the studies on the issue of improving their training were reviewed. Objective. To analyse the sports performance of Ukrainian fencers at the Tokyo Olympics. Methods. Analysis of literature sources, data from the Internet, and technical reports. Results. The study revealed that the performance of the national team of Ukraine at the Games of XXXII Olympiad can be considered satisfactory. It is noted that currently, the system of fencing development in Ukraine is far from optimal. There is a clear shortage of modern training centers for athletes, inefficient budgetary and extrabudgetary funding, imperfect legal, organizational and managerial, scientific and methodological, medical, informational, and staffing support. Thus, the fencing development strategy in the modern conditions of Ukraine's development requires the formation and scientific substantiation of conceptual foundations for the successful and dynamic development of this sport. PEST analysis was performed to assess the current state of functioning and development of fencing sport. It was found that the most significant factors are: legislative

Driukov 0., Driukov V. Fencing at the XXXI Olympic Games in Tokyo: results and directions of improving Olympic training. Theory and Methods of Physical education and sports. 2021; 3: 20-27 DOI: 10.32652/tmfvs.2021.3.20-27
Дрюков О. В., Дрюков В.О. Фехтування на Іграх XXXII Олімпіади в Токіо: підсумки і напрями вдосконалення олімпійської підготовки. Теорія і методика фрізичного виховання і спорту. 2021; 3: 20-27 DOI: 10.32652/tmfvs.2021.3.20-27
13. Borysova O, Nagorna V, Pavlenko I, Shutova S, Mytko A, Shlonska 0, Peretyatyko A, Tkachenko M, Sushko R. Psychological readiness of elite and well-trained billiard players for the main competitions of the macrocycle. SportMont. 2021;19(2021):101-6.

Надійшла 20.09.2021

Вступ. Одним з основних показників розвитку фехтування у світі $€$ результати виступу спортсменів на Олімпійських іграх. Головним критерієм рівня розвитку фехтування в країні $€$ завоювання золотих медалей і призових місць.

Сьогодні перемога на Олімпійських іграх сприймається як успіх не тільки окремого спортсмена, а й країни, представником якої він є, що приводить до гострої боротьби в неофіційному командному заліку. В цілому це висунуло проблему вдосконалення організаційно-управлінських напрямів розвитку олімпійських видів спорту [3].

У ряді робіт [1, 2, 5, 6, 8] розглянуто різні аспекти розвитку олімпійських видів спорту. Ученими показано, що в умовах ринкових відносин, комерціалізації та просресіоналізації спорту вищих досягнень великого значення набуває модернізація організаційно-управлінських форм функціонування і розвитку видів спорту. Отже, актуальним стає пошук способів їх подальшого вдосконалення у сучасних умовах розвитку України.

Мета дослідження - проаналізувати спортивні результати українських фехтувальників на Іграх XXXII Олімпіади та визначити шляхи розвитку фехтування як олімпійського виду спорту.

Методи дослідження: аналіз літературних джерел, інформаційної мережі Інтернет, технічних протоколів Ігор XXXII Олімпіади, опитування, методи математичної статистики.

Результати дослідження. На Іграх XXXII Олімпіади в Токіо у змаганнях 3 фехтування брали участь 212 спортсменів з 42 країн [9]. Розподіл олімпійських нагород подано у таблиці 1. 
support for the development of sports in the group of political factors; financing and logistics of sports schools in the group of economic factors; the level of coaching and teaching staff and working conditions in sports schools among the social factors; and innovative technologies and their impact on the development of fencing in the group of technological factors. The results of the study showed that the development of fencing is hampered by a number of macro-environmental factors and conditions that require certain reforms. As research shows, the process of functioning and development of fencing sport in modern conditions requires the formation of fundamentally new economic foundations and the search for organizational and legal forms of their functioning. In our opinion, this is a transition from the extensive model of sports development currently used in Ukraine to the innovative one. Thus, in order to ensure winning medals in future Olympics, it is required to develop a model of innovative development of fencing sport based on a strategic partnership among the government, public sports organizations, sports science, education, and business.

Keywords: Olympic Games, outcomes, PEST-analysis, fencing sport.

У Токіо олімпійські медалі завоювали спортсмени 313 країн і дев'ять 3 них здобули золоті нагороди. У цілому змагання виявили явну перевагу спортсменів ОКР, Франції, Кореї, які завоювали 18 медалей, з них шість золотих. Несподівано слабко виступили команди Румунії, України, Німеччини, в складах яких багато спортсменів високого класу - лідерів світового фрехтування, які були серйозними конкурентами.

Коротко розглянемо основні підсумки Ігор XXXII Олімпіади у різних видах зброї.

Шпага (чоловіча). у змаганнях 3 фехтування на шпагах в особистій першості змагалися 36 спортсменів 318 країн. Головними фаворитами на завоювання олімпійських медалей в особистій першості вважали Г. Шіклоші (Угорщина), С. Біда (ОКР), І. Рейзліна (Україна) - лідерів світового рейтингу FIE, володарів золотої, срібної та бронзової медалей на чемпіонаті світу 2019 р.; Я. Бореля (Франція) - чемпіона світу та Європи 2018 р.; Пак Сан Йон (Корея) - олімпійського чемпіона 2016 p.

В особистих змаганнях 3 фехтування на шпагах взяли участь три представники України: І. Рейзлін, Б. Нікішин та Р. Свічкар. Четвертий учасник, А. Герей, брав участь лише у командних змаганнях.

Українські спортсмени почали олімпійський турнір 3 1/32 фріналу. Б. Нікішин програв Лань Мін Хао (Китай) $з$ рахунком 12:13 і посів 19-те місце. Р. Свічкар програв М. Хайнцеру (Швейцарія) - 11:15 і посів 22-ге місце. І. Рейзлін у першому колі переміг Б. Штейфана (Швейцарія) із рахунком 15:11, у другому колі він переміг М. Хайнецера (Швейцарія) із рахун- ком 15:12, у третьому колі переміг із рахунком 15:13 Махамеда Ель-Саєда (Єгипет). У півфрінальному двобої І. Рейзлін програв Р. Каннон (Франція) на Іграх XXXII Олімпіади в Токіо
10:15. У поєдинку за бронзову нагороду він переміг А. Санатареллі (Італія) 15:12. Фінал завершився перемогою Р. Каннона (Франція) над Г. Шіклоші (Угорщина) (табл. 2).

у командних змаганнях брали участь дев'ять збірних. Фаворитами на завоювання медалей вважали команди Франції, Італії та України - лідерів світового рейтингу FIE.

Збірна команда України розпочала виступ зі стадії чвертьфріналу, де за вихід у півфінал зустрілась зі збірною командою Китаю, але програла з рахунком 35:45. Потім перемога над збірною командою Італії з рахунком

T а б л и ц я 1. Розподіл медалей на Іграх XXXII Олімпіади у змаганняХ з феетування

\begin{tabular}{|l|l|l|l|l|l|}
\hline \multirow{2}{*}{ Місце } & \multirow{2}{*}{ Країна } & \multicolumn{3}{c|}{ Кількість медалей } & \multirow{2}{*}{ Усього } \\
\cline { 3 - 6 } & & 3 & $\mathbf{C}$ & $\mathbf{5}$ & \\
\hline 1-ше & ОКР & 3 & 4 & 1 & 8 \\
\hline 2-ге & Франція & 2 & 2 & 1 & 5 \\
\hline 3-те & Корея & 1 & 1 & 3 & 5 \\
\hline 4-те & Угорщина & 1 & 1 & 1 & 3 \\
\hline 5-те & Естонія & 1 & 0 & 1 & 2 \\
\hline 6-те & США & 1 & 0 & 1 & 2 \\
\hline 7-ме & КНР & 1 & 0 & 0 & 1 \\
\hline 8-ме & Гонконг & 1 & 0 & 0 & 1 \\
\hline 9-те & Японія & 1 & 0 & 0 & 1 \\
\hline 10-те & Ііталія & 0 & 3 & 2 & 5 \\
\hline 11-те & Румунія & 0 & 1 & 0 & 1 \\
\hline 12-те & Україна & 0 & 0 & 1 & 1 \\
\hline 13-те & Чехія & 0 & 0 & 1 & 1 \\
\hline
\end{tabular}

Примітки: ОКР - Олімпійський комітет Росії; 3 - золоті, С - срібні, Б - бронзові

Т а б л и ц я 2. Підсумки особистих змагань з фехтування на шпагах серед чоловіків

\begin{tabular}{|c|c|c|c|c|c|c|}
\hline Місце & Спортсмен & Країна & $\begin{array}{c}\text { Biк, } \\
\text { років }\end{array}$ & $\begin{array}{c}\text { Рейтинг } \\
\text { у світі }\end{array}$ & $\begin{array}{l}\text { Місце на } \\
\text { чемпіонаті } \\
\text { світу } 2019 \text { р. }\end{array}$ & $\begin{array}{c}\text { Мiсце на Іграх } \\
\text { XXXI Oлімпіади } \\
\text { (2016 р.) }\end{array}$ \\
\hline 1-ше & Р. Каннон & Франція & 24 & 47-й & 30-те & Не брав участі \\
\hline 2-ге & Г. Шіклоші & Угорщина & 23 & $1-и ̆$ & 1-ше & Не брав участі \\
\hline 3-те & ì. Рейзлін & Україна & 37 & $3-и ̆$ & 3-те & Не брав участі \\
\hline 4-те & А. Сантареллі & їталія & 28 & $5-и ̆$ & 3-T€ & Не брав участі \\
\hline 19-те & Б. Нікішин & Україна & 41 & $12-\check{n}$ & 9-те & 10-те \\
\hline 22-ге & Р. Свічкар & Україна & 28 & $29-\breve{~}$ & 20-те & Не брав участі \\
\hline
\end{tabular}


Т а б л и ц я 3. Результати командних змагань з фехтування на шпагах серед чоловіків на Іграх XXXII Олімпіади в Токіо

\begin{tabular}{|l|l|c|c|c|c|}
\hline \multicolumn{1}{|c|}{ Місце } & \multicolumn{1}{|c|}{ Країна } & $\begin{array}{c}\text { Середній } \\
\text { вік, років }\end{array}$ & $\begin{array}{c}\text { Рейтинг у } \\
\text { світі }\end{array}$ & $\begin{array}{c}\text { Місце на чемпіонаті } \\
\text { світу 2019 p. }\end{array}$ & $\begin{array}{c}\text { Місце на Іграх XXXI } \\
\text { Олімпіади (2016 p.) }\end{array}$ \\
\hline 1-ше & Японія & 28,0 & 8-ма & 9-те & Не брала участі \\
\hline 2-ге & ОКР & 32,0 & 7-ма & 7-ме & 7-ме \\
\hline 3-те & Корея & 28,6 & 5-та & 6-те & 5-те \\
\hline 4-те & Китай & 27,3 & 6-та & 4-те & Не брала участі \\
\hline 6-те & Україна & 35,3 & 3-тя & 2-ге & 4-те \\
\hline
\end{tabular}

Т а б л и ц я 4. Підсумки особистих змагань з фрехтування на шпагах серед жінок на Іграх XXXII Олімпіади в Токіо

\begin{tabular}{|c|c|c|c|c|c|c|}
\hline Місце & Спортсменка & Країна & $\begin{array}{l}\text { Biк, } \\
\text { років }\end{array}$ & $\begin{array}{l}\text { Рейтинг } \\
\text { у світі }\end{array}$ & $\begin{array}{l}\text { Місце на } \\
\text { чемпіонаті } \\
\text { світу } 2019 \text { р. }\end{array}$ & $\begin{array}{l}\text { Мiсце на Іграх } \\
\text { XXXI Олімпіади } \\
\text { (2016 р.) }\end{array}$ \\
\hline 1-ше & Сунь Ївень & Китай & 29 & 3-тя & 10-те & 3-те \\
\hline 2-ге & А. Попеску & Румунія & 36 & 1-ша & 9-те & 9-те \\
\hline 3-тє & К. Лexic & Естонія & 26 & 12-та & 13-те & $\begin{array}{l}\text { Не брала } \\
\text { участі }\end{array}$ \\
\hline 4-те & А. Муртазаєва & OKP & 19 & 258-ма & $\begin{array}{l}\text { Не брала } \\
\text { участі }\end{array}$ & $\begin{array}{l}\text { Не брала } \\
\text { участі }\end{array}$ \\
\hline 21-ше & О. Кривицька & Україна & 34 & 10-та & 3-т€ & 15-те \\
\hline
\end{tabular}

T а б л и ц я 5. Результати командних змагань з фехтування на шпагах серед жінок на Іграх XXXII Олімпіади в Токіо

\begin{tabular}{|l|l|c|c|c|c|}
\hline \multicolumn{1}{|c|}{ Місце } & \multicolumn{1}{|c|}{ Країна } & $\begin{array}{c}\text { Середній } \\
\text { вік, років }\end{array}$ & $\begin{array}{c}\text { Рейтинг } \\
\text { у світі }\end{array}$ & $\begin{array}{c}\text { Місце на чемпіонаті } \\
\text { світу 2019 р. }\end{array}$ & $\begin{array}{c}\text { Місце на Іграх XXXI } \\
\text { Олімпіади (2016 р.) }\end{array}$ \\
\hline 1-ше & Естонія & 28,0 & 7-ма & 6-те & 4-те \\
\hline 2-ге & Корея & 31,3 & 4-та & 7-ме & 6-те \\
\hline 3-тє & Їталія & 29,0 & 6-та & 3-тє & Не брала участі \\
\hline 4-те & Китай & 28,3 & 1-ша & 1-ше & 2-ге \\
\hline
\end{tabular}

45:39 за 5-8-ме місце і поразка від збірної Франції з рахунком 39:45 за 5-6-те місце. У результаті збірна команда України посіла 6-те місце.

Результати командних змагань у фрехтуванні на шпагах серед чоловіків наведено у таблиці 3. Золоті медалі завоювала збірна команда Японії, яка у чвертьфріналі перемогла збірну команду Франції - лідера світового рейтингу FIE, чемпіона світу 2019 р., а у фріналі перемогла збірну команду ОКР.

Шпага (жіноча). У змаганнях 3 фрехтування на шпагах в особистій першості змагались 34 спортсменки 318 країн.
Головними фаворитами на завоювання олімпійських медалей в особистій першості вважали А. Попеску (Румунія), Чхве Ін Джон (Корея), Сунь Івень (Китай) - лідерів світового рейтингу FIE, чемпіонку світу 2019 р. Н. Моельхаузен (Бразилія), М. Наваррія (Італія) - чемпіонку світу 2018 р.

Україну на Іграх XXXII Олімпіади представляла 0. Кривицька, яка потрапила на змагання через зональний відбір. Вона у першому двобої програла Р. Кнапік-Мязда (Польща) з рахунком 8:15. В підсумковому протоколі посіла 21-ше місце.

Олімпійською чемпіонкою стала 29-річна Сунь Івень (Китай), яка у фіна- лі перемогла лідера світового рейтингу FIE A. Попеску (Румунія) (табл. 4)

У командних змаганнях брали участь вісім країн. Збірна команда України у цьому виді зброї участі не брала.

Фаворитами на завоювання медалей вважали команди Китаю, Польщі, ОКР, Кореї - лідерів світового рейтингy FIE.

Результати командних змагань у фрехтуванні на шпагах серед жінок наведено у таблиці 5. Золоті медалі завоювала збірна команда Естонії у складі Ю. Беляєвой, І. Ембріх, Е. Кірпу і K. Лexic.

Шабля (жіноча). У змаганнях 3 фехтування на шаблях в особистій першості змагались 36 спортсменок 318 країн.

Головними ффаворитами на завоювання олімпійських медалей в особистій першості вважали 0. Харлан (Україна), С. Вєлікую (ОКР), М. Брюне (Франція) - лідерів світового рейтингу FIE, С. Позднякову (OKP) - чемпіонку світу 2018 p.

Україну на Іграх XXXII Олімпіади представляла 0. Харлан згідно 3 особистим рейтингом FIE. У першому раунді вона (перший номер посіву на олімпійському турнірі) поступилася китаянці Янг Хенюй (28-й номер посіву на олімпійському турнірі) 3 рахунком 12:15. Ігри в Токіо стали для 0. Харлан четвертими в кар'єрі: на кожній з трьох попередніх Олімпіад вона здобувала медаль (одна 30лота, одна срібна, дві бронзові), а в Японію приїхала у статусі чинної чемпіонки світу і лідера світового рейтингу FIE. У підсумковому протоколі посіла 17-те місце.

Результати особистих змагань у фрехтуванні на шаблях серед жінок на Iграх XXXII Олімпіади наведено у таблиці 6. Олімпійською чемпіонкою стала 24-річна С. Позднякова (ОКР), чемпіонка світу 2018 р., яка у фіналі перемогла співвітчизницю С. Вєлікую.

y командних змаганнях брали участь дев'ять країн. Збірна команда України у цьому виді зброї участі не брала.

Головними фраворитами на завоювання медалей вважали команди ОКР, Італії, Франції та Кореї - лідерів світо- 
Т а б л и ц я 6. Підсумки особистих змагань з фехтування на шаблях серед жінок на Іграх XXXII Олімпіади в Токіо

\begin{tabular}{|c|l|l|c|c|c|c|}
\hline Місце & Спортсменка & \multicolumn{1}{|c|}{ Країна } & Вік, років & Рейтинг у світі & $\begin{array}{c}\text { Місце на чемпіонаті світу } \\
\mathbf{2 0 1 9} \mathbf{p .}\end{array}$ & $\begin{array}{c}\text { Місце на Іграх XXXI } \\
\text { Олімпіади (2016 p.) }\end{array}$ \\
\hline 1-ше & С. Позднякова & ОКР & 24 & 17-та & 33-тє & Не брала участі \\
\hline 2-ге & С. Вєлікая & ОКР & 36 & 2-га & 2-ге & 2-ге \\
\hline 3-тє & М. Брюнет & Франція & 25 & 3-тя & 9-те & 4-те \\
\hline 4-те & А. Мартон & Угорщина & 26 & 5-та & 7-ме & 3-те \\
\hline 17-те & О. Харлан & Україна & 30 & 1-ша & 1-ше & -те \\
\hline
\end{tabular}

T а б л и ц я 7. Результати командних змагань з фехтування на шаблях серед жінок на Іграх XXXII Олімпіади в Токіо

\begin{tabular}{|c|l|c|c|c|c|}
\hline Місце & \multicolumn{1}{|c|}{ Країна } & Середній вік, років & Рейтинг у світі & $\begin{array}{c}\text { Місце на чемпіонаті світу } \\
\text { 2019 p. }\end{array}$ & $\begin{array}{c}\text { Місце на Іграх XXXI } \\
\text { 0лімпіади (2016 p.) }\end{array}$ \\
\hline 1-ше & ОКР & 27,3 & 1-ша & 1-ше & 1-ше \\
\hline 2-ге & Франція & 29,6 & 3-тя & 2-ге & 8-ме \\
\hline 3-тє & Корея & 30,3 & 4-та & 3-тє & 5-те \\
\hline 4-те & Ііталія & 29,6 & 2-га & 4-те & 4-те \\
\hline
\end{tabular}

Т а б л и ц я 8. Підсумки особистих змагань з фрехтування на шаблях серед чоловіків на Іграх XXXII Олімпіади в Токіо

\begin{tabular}{|c|c|c|c|c|c|c|}
\hline Місце & Спортсмен & Країна & Вік, років & Рейтинг у світі & $\begin{array}{c}\text { Місце на чемпіонаті світу } \\
2019 \mathrm{p} .\end{array}$ & $\begin{array}{l}\text { Місце на Iграх XXXI } \\
\text { Олімпіади (2016 p.) }\end{array}$ \\
\hline 1-ше & А. Сіладьї & Угорщина & 31 & 4-й & 19-те & 1-ше \\
\hline 2-ге & л. Самеле & Ііталія & 33 & $11-и ̆$ & 13-те & Не брав участі \\
\hline 3-тє & Кім Чжон Хван & Корея & 37 & $15-и ̆$ & 18-те & 3-TE \\
\hline 4-те & С. Базадзе & Грузія & 27 & 7-й & 12-те & 13-те \\
\hline
\end{tabular}

вого рейтингу FIE. Результати командних змагань 3 фехтування на шаблях серед жінок наведено у таблиці 7. Олімпійським чемпіоном, прогнозовано, стала збірна команда ОКР - чинний чемпіон світу та Олімпійських ігор 2016 p.

Шабля (чоловіча). У змаганнях 3 фехтування на шаблях в особистій першості змагались 36 спортсменів 3 18 країн. Українські спортсмени у цьому виді зброї участі не брали.

Головними фаворитами на завоювання олімпійських медалей в особистій першості вважали О Сан Ук (Корея), Е. Дершвіц (США), Л. Каратолі (Італія), А. Сіладьї (Угорщина) - лідерів світового рейтингу FIE, A. Сатмарі (Угорщина) - чемпіона світу 2017 р. Кім Джон Хван (Корея) - чемпіона світу 2018 р. Результати особистих змагань у фехтуванні на шаблях серед чо- ловіків на Іграх XXXII Олімпіади наведено у таблиці 8.

Олімпійську золоту нагороду здобув 31-річний А. Сіладьї (Угорщина), який став триразовим олімпійським чемпіоном. До Ігор в Токіо він перемагав на Іграх у Лондоні (2012р.) і Ріоде-Жанейро (2016 р.). Срібну медаль отримав Л. Самеле (Італія), бронзову - Кім Чон Хван (Корея).

Т а б л и ц я 9. Результати командних змагань з фехтування на шаблях серед чоловіків на Іграх XXXII Олімпіади в Токіо

\begin{tabular}{|c|c|c|c|c|c|}
\hline Місце & Країна & $\begin{array}{l}\text { Середній } \\
\text { вік, років }\end{array}$ & $\begin{array}{l}\text { Рейтинг } \\
\text { у світі }\end{array}$ & $\begin{array}{l}\text { Місце на чемпіонаті } \\
\text { світу } 2019 \text { р. }\end{array}$ & $\begin{array}{l}\text { Місце на Іграх XXX } \\
\text { Олімпіади (2016 p.) }\end{array}$ \\
\hline 1-ше & Корея & 31,0 & 1-ша & 1-ше & \multirow{4}{*}{$\begin{array}{l}\text { Змагання } \\
\text { не відбувалися }\end{array}$} \\
\hline 2-ге & І̇талія & 29,6 & 3-тя & 3-тє & \\
\hline 3-тє & Угорщина & 32,3 & 2-га & 2-ге & \\
\hline 4-те & Німеччина & 30,3 & 4-та & 4-те & \\
\hline
\end{tabular}

у командних змаганнях брали участь спортсмени дев'яти країн. Українські фехтувальники в цьому виді зброї участі не брали.

Головними фраворитами на завоювання медалей вважали команди Кореї, Угорщини, Італії, Німеччини - лідерів світового рейтингу FIE.

Результати командних змагань 3 фехтування на шаблях серед чоловіків наведено у таблиці 9. Олімпійським 
Т а б л и ц я 10. Підсумки особистих змагань з фехтування на рапірах серед жінок на Іграх XXXII Олімпіади в Токіо

\begin{tabular}{|c|c|c|c|c|c|c|}
\hline Місце & Спортсмен & Країна & Вік, років & Рейтинг у світі & $\begin{array}{c}\text { Місце на чемпіонаті світу } \\
\text { 2019 р. }\end{array}$ & $\begin{array}{c}\text { Місце на Іграх } \mathbf{X X X I} \\
\text { 0лімпіади (2016 p.) }\end{array}$ \\
\hline 1-ше & Лі Кіфер & США & 27 & 5 -та & 5-те & 10-те \\
\hline 2-ге & І. Дериглазова & ОКР & 31 & 1-ша & 1-ше & 1-ше \\
\hline 3-тє & Л. Коробейникова & ОКР & 34 & 18-та & 20-те & Не брала участі \\
\hline 4-те & А. Вольпі & Ііталія & 29 & 4-та & 17-те & Не брала участі \\
\hline
\end{tabular}

T а б л и ц я 11. Результати командних змагань з фехтування на рапірах серед жінок на Іграх XXXII Олімпіади в Токіо

\begin{tabular}{|c|c|c|c|c|c|}
\hline Місце & Країна & Середній вік, років & Рейтинг у світі & $\begin{array}{c}\text { Місце на чемпіонаті світу } \\
2019 \text { р. }\end{array}$ & $\begin{array}{l}\text { Місце на Iграх XXXI } \\
\text { Олімпіади (2016 p.) }\end{array}$ \\
\hline 1-ше & OKP & 31,0 & 1-ша & 1-ше & \multirow{4}{*}{$\begin{array}{l}\text { Змагання } \\
\text { не відбувалися }\end{array}$} \\
\hline 2-ге & Франція & 28,3 & 3-тя & 4-те & \\
\hline 3-тє & І̇талія & 31,3 & 2-га & 2-ге & \\
\hline 4-те & США & 28,6 & 4-та & 3-T€ & \\
\hline
\end{tabular}

Т а б л и ц я 12. Підсумки особистих змагань з фехтування на рапірах серед чоловіків на Іграх XXXII Олімпіади в Токіо

\begin{tabular}{|c|c|c|c|c|c|c|}
\hline Місце & Спортсмен & Країна & Вік, років & Рейтинг у світі & $\begin{array}{l}\text { Місце на чемпіонаті світу } \\
2019 \mathrm{p} .\end{array}$ & $\begin{array}{l}\text { Місце на Iграх XXXI } \\
\text { Олімпіади (2016 p.) }\end{array}$ \\
\hline 1-ше & Ка Лун Чон & Гонконг & 24 & 19-й & 7-ме & 14-те \\
\hline 2-ге & Д. Гараццо & Ііталія & 28 & 7-й & 9-те & 1-ше \\
\hline 3-T€ & О. Чупеніг & Чехія & 27 & $27-и ̆$ & 28-ме & 26-те \\
\hline 4-те & Т. Сікіне & Японія & 23 & 12-й & 40-ве & Не брав участі \\
\hline
\end{tabular}

чемпіоном, прогнозовано, стала збірна команда Кореї - чинний чемпіон світу, лідер світового рейтингу FIE.

Paпiра (жіноча). У змаганнях 3 фехтування на рапірах в особистій першості змагалися 34 спортсменки з 18 країн. Українські фехтувальниці у цьому виді зброї участі не брали.

Головними фаворитами на завоювання олімпійських медалей в особистій першості вважали І. Дериглазову (ОКР), Е ді Франциску (Італія), І. Тібус (Франція), А. Вольпі (Італія), Лі Кіфер (США) - лідерів світового рейтингу FIE.

Результати особистих змагань у фехтуванні на рапірах серед жінок на Іграх XXXII Олімпіади наведено у таблиці 10. Олімпійською чемпіонкою стала 27-річна Лі Кіфер (США), яка у фіналі перемогла І. Дериглазову (ОКР) - чинну чемпіонку світу і Олімпійських ігор 2016 р., лідера світового рейтингу FIE - 3 рахунком 15:13. Бронзову медаль завоювала Л. Коробейнікова (ОКР).

У командних змаганнях брали участь спортсменки 3 дев'яти країн. Українські фехтувальниці в цьому виді зброї участі не брали.

Головними фаворитами на завоювання медалей вважали команди ОКР, Італії, Франції, США - лідерів світового рейтингу FIE. Результати командних змагань 3 фехтування на рапірах серед жінок наведено у таблиці 11. Олімпійським чемпіоном, прогнозовано, стала збірна команда ОКР - чинний чемпіон світу, лідер світового рейтингу FIE.

Рапіра (чоловіча). У змаганнях 3 фехтування на рапірах в особистій першості змагалися 36 спортсменів 3 18 країн. Українські спортсмени у цьому виді зброї участі не брали.

Головними фаворитами на завоювання олімпійських медалей в осо- бистій першості вважалися А. Факоні (Італія), Г. Мейнгард (США), Е. Лесор (Франція).

Результати особистих змагань у фехтуванні на рапірах серед чоловіків на Іграх XXXII Олімпіади наведено у таблиці 12. Олімпійським чемпіоном став 24-річний Ка Лун Чон (Гонконг), який у фріналі переміг чинного чемпіона Олімпійських ігор 2016 р. Д. Гараццо (Італія) з рахунком 15:11. Бронзову медаль завоював А. Чупеніг (Чехія).

у командних змаганнях брали участь фехтувальники дев'яти країн. Українські спортсмени у цьому виді зброї участі не брали.

Головними фраворитами на завоювання медалей вважали команди США, Франції, Італії, ОКР, Гонконгу - лідерів світового рейтингу FIE. Peзультати командних змагань 3 фехтування на рапірах серед чоловіків наведено у таблиці 13. Олімпійським чемпіоном стала збірна команда Франції. 
Т а б л и ц я 13. Результати командних змагань з фехтування на рапірах серед чоловіків на Іграх XXXII Олімпіади в Токіо

\begin{tabular}{|c|c|c|c|c|c|}
\hline Місце & Країна & $\begin{array}{c}\text { Середній } \\
\text { вік, років }\end{array}$ & $\begin{array}{c}\text { Рейтинг у } \\
\text { світі }\end{array}$ & $\begin{array}{c}\text { Місце на чемпіонаті } \\
\text { світу 2019 p. }\end{array}$ & $\begin{array}{c}\text { Місце на Іграх XXXI } \\
\text { 0лімпіади (2016 p.) }\end{array}$ \\
\hline 1-ше & Франція & 30,0 & 2-га & 2-ге & 2-ге \\
\hline 2-ге & ОКР & 20,6 & 4-та & 4-те & 1-ше \\
\hline 3-тє & США & 26,3 & 1-ша & 1-ше & 3-тє \\
\hline 4-те & Японія & 23,6 & 7-ма & 9-те & Не брала участі \\
\hline
\end{tabular}

Чинний чемпіон світу, лідер світового рейтингу FIE команда США у півфіналі програла збірній команді ОКР і у підсумку посіла третє місце.

Результати змагань 3 фехтування на Іграх XXXII Олімпіади в різних видах зброї показали, що в умовах найгострішої конкуренції, яка була практично у всіх видах змагань, завоювання медалей визначали здатністю спортсменів вийти на найвищий рівень готовності в день старту.

На Іграх XXXII Олімпіади в Токіо українські фехтувальники (6 осіб) змагалися у чотирьох видах змагань 3 дванадцяти. Як наголошувалось вище, завойовано одну бронзову медаль і 12-13-те місце у медальному заліку (див. табл. 1). Виступ збірної команди України можна вважати задовільним.

Результати Ігор XXXII Олімпіади в Токіо дають змогу говорити про певні тенденції розвитку фехтування у світі.

По-перше, винятково висока конкуренція та гостра спортивна бороть- ба у змаганнях з усіх видів зброї. Про дуже високе загострення спортивної боротьби свідчить те, що жоден чинний чемпіон світу в особистій першості серед жінок (0. Харлан (Україна) шабля, А. Попеску (Румунія) - шпага, І. Дериглазова (Росія) - рапіра), серед чоловіків (0 Сан Ук (Корея) - шабля, О. Біда (Росія) - шпага, Е. Лефор (Франція) - рапіра) не зміг завоювати золоту медаль.

По-друге, медалі в командній першості завоювали збірні, які змогли протягом п'яти років олімпійського циклу (2017-2021 рр.) зберегти стабільний склад і мали лідерів у кожному виді зброї.

По-третє, розширення вікових діапазонів переможців та призерів Ігор XXXII Олімпіади. Середній вік серед жінок - 29,7 року, найстарші - С. Вєлікая (Росія) - шабля, А. Попеску (Румунія) - шпага, 36 років, наймолодша С. Позднякова (Росія) - шабля, олімпійська чемпіонка, 24 роки. Середній вік переможців та призерів серед чо- ловіків - 29,3 року, найстарші - І. Рейзлін (Україна) - шпага, Ким Чжон Хван (Корея) - шабля, 37 років, наймолодші олімпійські чемпіони Р. Каннон (Франція) - шпага, Ка Лун Чон (Гонконг) - рапіра, 24 роки.

По-четверте, тенденція до більш раціонального використання найближчих резервів збірної команди країни. Найефективніше й у короткий термін вводять молодих спортсменів до еліти світового фехтування в Росії, Франції, Гонконгу, Японії.

Дискусія. Одним із основних показників розвитку спорту вищих досягнень у світі $€$ результати виступу спортсменів на Олімпійських іграх. Порівняльний аналіз статистичного матеріалу участі спортсменів незалежної України в Іграх XXVI-XXXII Олімпіад (табл. 14) свідчить про те, що зменшилась кількість учасників Олімпіад, в Токіо повторення найгіршого результату: шість ліцензій раніше українські фехтувальники здобували лише одного разу - у 1996 р.; зменшується кількість командних видів зброї (на Іграх XXXII Олімпіади в Токіо в командних видах змагалася лише чоловіча збірна команда України зі шпаги); кількість видів зброї, в яких вибороли медалі.

Аналіз результатів українських спортсменів на Іграх XXXII Олімпіади дають змогу вказати на фрактори слабкого їх виступу в особистих змаганнях у жіночій шаблі та шпазі, а також у чоловічих командних змаганнях

T а б л и ц я 14. Статистичні дані участі спортсменів незалежної України в Іграх XXVI-XXXII Олімпіад у змаганняX 3 фрехтування

\begin{tabular}{|c|c|c|c|c|c|c|c|c|}
\hline \multirow{3}{*}{ Ігри Олімпіад } & \multicolumn{7}{|c|}{ Кількість } & \multirow{3}{*}{$\begin{array}{r}\text { Усього } \\
\text { медалеі }\end{array}$} \\
\hline & \multirow{2}{*}{ Учасників } & \multirow{2}{*}{$\begin{array}{l}\text { Медалей, що } \\
\text { розігрують }\end{array}$} & \multirow{2}{*}{$\begin{array}{l}\text { Видів зброї, в яких } \\
\text { завойовано медалі }\end{array}$} & \multirow{2}{*}{$\begin{array}{l}\text { Спортсменів, які } \\
\text { вибороли медалі }\end{array}$} & \multicolumn{3}{|c|}{ Медалей } & \\
\hline & & & & & 3 & C & Б & \\
\hline XXVI, Атланта, 1996 р. & 6 & 10 & 0 & 0 & 0 & 0 & 0 & 0 \\
\hline XXVII, Сідней, 2000 р. & 10 & 10 & 0 & 0 & 0 & 0 & 0 & 0 \\
\hline XXVIII, Афіни, 2004 р. & 10 & 10 & 1 & 1 & 0 & 0 & 1 & 1 \\
\hline XXIX, Пекін, 2008 р. & 10 & 10 & 1 & $4^{\star}$ & 1 & 0 & 0 & 1 \\
\hline XXX, Лондон, 2012 р. & 8 & 10 & 2 & 2 & 1 & 0 & 1 & 2 \\
\hline XXXI, Ріо-де-Жанейро, 2016 р. & 14 & 10 & 1 & $4^{*}$ & 0 & 1 & 1 & 2 \\
\hline XXXII, Токіо, 2021 р. & 6 & 12 & 1 & 1 & 0 & 0 & 1 & 1 \\
\hline
\end{tabular}

Примітка. $4^{*}$ - командні змагання, де нагороджуються за перемогу чотири спортсмени 
на шпагах, незважаючи на можливості завоювання медалей у цих видах спорту, згідно з даними багатьох аналітиків, як компанії Infostrada Sports, так і інших експертів, що спеціалізуються на спортивній статистиці. До них, на наш погляд, належать:

- незадовільний рівень реалізації методики побудови заключного етапу підготовки спортсменів до олімпійських ігор;

- відсутність психологічної стійкості спортсменів на змаганнях;

- слабка тактична підготовка окремих спортсменів.

Ці дані відображають сучасний стан фехтування в країні та вказують на необхідність його вдосконалення. На нашу думку, сьогодні система розвитку олімпійських видів спорту в Україні не є оптимальною. Спостерігається явний десріцит сучасних центрів підготовки, неесективне бюджетне і позабюджетне фрінансування, недосконалість нормативно-правового та організаційно-управлінського, науково-методичного, медичного, інфрормаційного та кадрового забезпечення.

Таким чином, стратегія розвитку фехтування як олімпійського виду спорту в сучасних умовах розвитку України вимагає формування та наукового обґрунтування концептуальних основ для успішного і динамічного його розвитку.

Для оцінювання сучасного стану фрункціонування і розвитку фехтування було проведено PEST-аналіз на матеріалі дитячо-юнацької спортивної школи (ДЮСШ) 3 фехтування Київської міської ради «Динамо» [4]. PEST-аналіз - це маркетинговий інструмент, призначений для виявлення політико-правових економічних, соціальних і технологічних аспектів зовнішнього середовища які впливають на розвиток галузі/організації і складається на 3-5 років наперед [7]. Як експертів було залучено 12 компетентних срахівців 3 фехтування: провідні тренери, члени комплексної наукової групи збірної команди України 3 фрехтування. Ними сформовано перелік основних політико-правових економічних, соціальних і технологічних фракторів, які можна віднести до можливостей та загроз зовнішнього макросередовища.
Результати досліджень свідчать про те, що в групі політико-правових фракторів найбільш значущими за рівнем вагомості $є$ законодавча підтримка розвитку видів спорту в державі $(0,33)$ та державна політика розвитку фехтування в країні $(0,32)$ В групі економічних факторів найбільш істотними $€$ фрінансування матеріально-технічне забезпечення спортивних шкіл $(0,33)$, інвестиційна політика у сфрері розвитку фехтування $(0,31)$, забезпечення основними засобами фрункціонування спортивних шкіл $(0,30)$. У групі соціальних факторів вирішальними є рівень тренерсько-викладацьких кадрів та умов праці у спортивних школах країни $(0,18)$, від'їзд за кордон талановитих тренерів і перспективних спортсменів $(0,16)$. У групі технологічних факторів найбільш значущими визначено інноваційні технології та їх вплив на розвиток фехтування $(0,32)$, тенденції науково-дослідних і дослідноконструкторськихробіт (НДДКР) $(0,18)$ та нормативно-методичне забезпечення навчально-спортивного процесу підготовки спортсменів $(0,18)$.

Як свідчить аналіз, великого значення для розвитку фрехтування у спортивних організаціях набувають політико-правові фактори, які чинять вагомий вплив на діяльність спортивних шкіл. Це пов'язано з тим, що діяльність спортивних шкіл потребує від держави вирішення багатьох питань як суто навчально-методичних пов'язаних із підготовкою спортсменів, так і правових, які встановлюють правила і норми розвитку видів спорту. Сучасне політико-правове середовище не зовсім сприятливе для ефективної реалізації стратегії розвитку фехтування у спортивних школах України. Найбільшу загрозу становить недосконалість чинних законодавчих та нормативно-правових документів усіх рівнів, що не дають змоги забезпечити необхідні умови для реалізаціі організаційно-управлінських, фрінансових, матеріально-технічних, кадрових, навчально-методичних, медичних та інших засад для нормативного функціонування системи розвитку видів спорту.
Значний вплив на розвиток фрехтування у спортивних організаціях належить економічним сракторам. Проведений аналіз виявив проблему у фрінансуванні і матеріально-технічному забезпеченні спортивних шкіл, що пов'язано з інвестиційною політикою держави у сфері розвитку видів спорту. Фінансування спортивних шкіл не в повному обсязі призвело до того, що їх матеріально-технічна база не відповідає сучасним вимогам підготовки спортсменів.

Соціальні фактори, як показали дослідження, чинять незначний вплив на розвиток фехтування. Проте, ї̈ деякі чинники, такі як рівень тренерськовикладацьких кадрів та умов праці у спортивних школах і від'їзд за кордон талановитих тренерів і перспективних спортсменів, знижують ефективність розвитку виду спорту. Таким чином, заходи управлінського характеру у соціальній сфері слід спрямовувати на підвищення рівня кваліфрікації тренерського складу та поліпшення рівня праці у спортивних школах.

Технологічні фоктори. Використання передових ідей і підходів до навчально-спортивного процесу спортсменів створює міцну основу для довгострокової і ефективної роботи спортивних шкіл. Однак, як показали дослідження, впровадження нових технологій, інновацій у розвиток феетування відбувається повільно у зв'язку 3 недостатнім фінансуванням для їх застосування, тому сьогодні використовуються застарілі технології, що гальмує розвиток сфрери. Ще одним фрактором інноваційної технології, що здійснює вплив на розвиток фехтування, $€$ нормативно-методичне забезпечення навчального процесу спортсменів, що характеризується високим ступенем консерватизму і низьким рівнем впровадження і розвитку інновацій. Таким чином, визначено низький рівень інноваційної активності спортивних шкіл.

Проведений PEST-аналіз показав, що сьогодні розвиток фехтування в ДЮСШ Київської міської ради «Динамо» гальмує ряд факторів макросередовища і умов, які потребують ефективного управління і проведення ряду ресрорм 
Як показує наше дослідження, процес фрункціонування і розвитку фехтування в сучасних умовах вимагає принципово нових економічних основ і пошуку нових організаційноправових фрорм їх функціонування. На нашу думку, це перехід від екстенсивної моделі розвитку видів спорту, яка сьогодні використовується в Україні, до інноваційної.

Отже, сьогодні особливо гостро стоїть питання наукового обґрунтування та розробки цільової соціальної програми розвитку олімпійських видів спорту в Україні.

\section{Висновки.}

Результати Ігор XXXII Олімпіади у Токіо дають змогу говорити про певні тенденції розвитку фехтування у світі.

По-перше, винятково висока конкуренція та гостра спортивна боротьба у змаганнях з усіх видів зброї.

По-друге, медалі в командній першості завоювали збірні, які змогли протягом п'яти років олімпійського циклу 2017-2021 рр. зберегти стабільний склад і мали лідерів у кожному виді зброї.

По-третє, розширення вікових діапазонів переможців та призерів Ігор XXXII Олімпіади.

Для забезпечення у подальшому завоювання золотих медалей і призових місць на Олімпійських іграх необхідно здійснити перехід від екстенсивної моделі розвитку фехтування, яка сьогодні використовується в Україні, до інноваційної - на основі стратегічного партнерства між державою, громадськими спортивними організаціями, наукою, ссрерою освіти і бізнесу.

У новому олімпійському циклі бажано якнайшвидше визначити кандидатів на участь в Іграх XXXIII Олімпіади в Парижі, які здатні досягти міжнародного рівня і реально претендувати на завоювання олімпійських медалей і створити їм усі умови для повноцінної підготовки.

Рівень досягнень збірної команди України в Парижі залежатиме від здатності тренерського складу зорієнтувати підготовку у черговому олімпійському циклі на максимальну сти- муляцію резервних можливостей спортсменів та виведення їх на найвищий рівень готовності до Ігор XXXIII Олімпіади 2024 р.

Перспективи подальших досліджень передбачають розробку Концепції розвитку олімпійських видів спорту в Україні.

Конфлікт інтересів. Автори заявляють, що відсутній будь-який конфрлікт інтересів.

\section{ЛIТЕРАТУРА}

1. Борисова О, Козлова Е. Профессионализация и коммерциализация в олимпийском спорте (на материале тенниса и легкой атлетики). Наука в олимпийском спорте. 2017;4:61-71.

2. Бубка СН, Платонов ВН, редакторы. Менеджмент подготовки спортсменов к Олимпийским играм. Киев: Олимпийская лит.; 2017. $480 \mathrm{c}$.

3. Дрюков 0, Дрюков В. Підсумки ви ступу олімпійської команди України на Іграх XXXI Олімпіади 2016 року у Ріо-де-Жанейро (Бразилія). Актуальні проблеми фрізичної культури і спорту. 2016;37(3):3-15.

4. Дрюков ОВ. Стратегічний аналіз впли ву макросередовища на розвиток спортивного фехтування в Україні. Науковий часопис НПу імені М. П. Драгоманова. Серія 15. Нау ково-педагогічні проблеми фрізичної культури (фрізична культура і спорт). 2020;7(127)20:7982.

5. Имас ЕВ, Борисова ОВ. Профессиональный теннис: проблемы и перспективы развития: монография. Киев: Олимпийская лит.; 2017. 288 c.

6. Платонов В, Есентаев Т. Организационноуправленческие модели подготовки спортсменов высокой квалификации в условиях политизации и коммерциализации олимпийского спорта. Наука в олимпийском спорте. 2015;2:19-26.

\section{ІНФОРМАЦІЯ ПРО АВТОРІВ}

Дрюков Олександр Володимирович https://orcid.org/0000-0002-3092-0719, alcadro@gmail. com

Хмельницький інститут соціальних технологій

29009, м. Хмельницький, вул. Ярослава Мудрого, 2а

Дрюков Володимир Олексійович https://orcid.org/0000-0002-0709-5597

Національний університет кораблебудування ім. адмірала Макарова

м. Миколаїв

\section{INFORMATION ABOUT THE AUTHORS}

Driukov Oleksandr https://orcid.org/0000-0002-3092-0719, alcadro@gmail.com

Khmelnytsky Institute of Social Technologies of university «UKRAINE»

29009, Khmelnytsky, 2a Yaroslava Mudroho str.

Driukov Volodymyr https://orcid.org/0000-0002-0709-5597

Admiral Makarov National University of Shipbuilding

Mykolayiv 